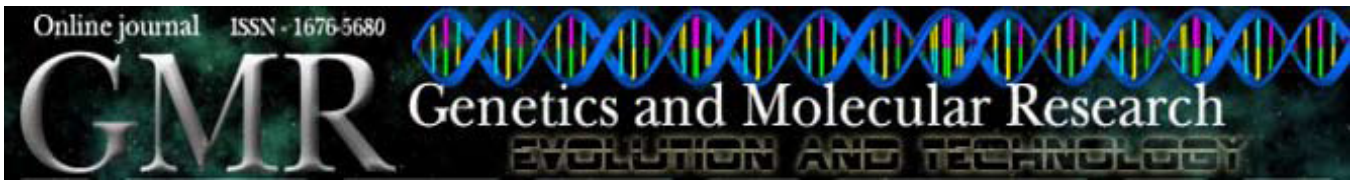

\title{
Characterization of the dry bean polygalacturonase-inhibiting protein (PGIP) gene family during Sclerotinia sclerotiorum (Sclerotiniaceae) infection
}

\author{
M.B. Oliveira ${ }^{1}$, L.B. Nascimento ${ }^{1}$, M.L. Junior ${ }^{2}$ and S. Petrofeza ${ }^{1}$ \\ ${ }^{1}$ Instituto de Ciências Biológicas, \\ Universidade Federal de Goiás, Goiânia, GO, Brasil \\ ${ }^{2}$ Embrapa Arroz e Feijão, Santo Antônio de Goiás, GO, Brasil \\ Corresponding author: S. Petrofeza \\ E-mail: petrofez@uol.com.br
}

Genet. Mol. Res. 9 (2): 994-1004 (2010)

Received January 22, 2010

Accepted February 22, 2010

Published June 1, 2010

DOI 10.4238/vol9-2gmr776

\begin{abstract}
Polygalacturonase-inhibiting proteins are leucine-rich repeat proteins that inhibit fungal endopolygalacturonases. The interaction of polygalacturonase-inhibiting protein with endopolygalacturonases limits the destructive potential of endopolygalacturonases and may trigger plant defense responses induced by oligogalacturonides. We examined the expression of fungal pg and plant Pvpgip genes in bean (Phaseolus vulgaris) stems infected with Sclerotinia sclerotiorum to determine whether any of them are associated with the infection process. Transcriptional analysis was carried out by means of semi-quantitative reverse transcription PCR or real-time PCR. The sspg1 gene was highly expressed during infection; sspg3 was regulated during the later phases of infection; sspg 5 was more uniformly expressed during infection, whereas sspg6 was only weakly expressed. During the course of infection, Pvpgip 1 transcripts were not detected at early stages, but they appeared $72 \mathrm{~h}$ post-inoculation. High levels of Pvpgip 2 expression were observed during the initial phase of infec-
\end{abstract}


tion; the transcript peaked by $48 \mathrm{~h}$ post-inoculation and declined by 72 h post-inoculation. Pvpgip3 expression increased strongly at 96 h post-inoculation. Pvpgip 4 was constantly present from 24 h postinoculation until the end of the experiment. However, we detected higher levels of the Pvpgip4 transcript in the necrotic lesion area than in plants that had been mechanically wounded. Remarkably, only Pvpgip 4 appeared to be moderately induced by mechanical wounding. These results provide evidence that endopolygalacturonases contribute to the infection process during host colonization by promoting the release of plant cell oligogalacturonides, which are powerful signaling molecules and may also activate plant defenses, such as polygalacturonase-inhibiting proteins.

Key words: Endopolygalacturonase; Phaseolus vulgaris; White mold; Polygalacturonase-inhibiting protein; Sclerotinia sclerotiorum

\section{INTRODUCTION}

White mold, caused by the ascomycete Sclerotinia sclerotiorum (Lib.) de Bary, is a significant cause of yield loss in Brazilian dry bean (Phaseolus vulgaris) crops. This pathogen survives in the soil for several years as sclerotia and has a very broad host range of more than 400 species, including many yearly crops and weeds, thus enabling fungal populations to persist and spread easily (Boland and Hall, 1994). Effective and economically feasible disease control is laborious and dry bean cultivars are at present highly susceptible to the disease.

To infect and colonize the plant tissues, most fungal pathogens need to overcome the structural barrier represented by plant cell wall. Cell wall-degrading enzymes are deputed to this function, and those able to depolymerize the pectic component of the middle lamellae and primary cell walls are the most intensely investigated (Alghisi and Favaron, 1995; Annis and Goodwin, 1997). The contribution of cell wall-degrading enzymes to the pathogenicity or virulence of fungi has been studied in several pathosystems. Endopolygalacturonases (PGs) are among the first enzymes secreted during the infection process and cleave the $\alpha(1-4)$ linkages between D-galacturonic acid residues in homogalacturonan, causing cell separation and maceration of host tissue. The genome of S. sclerotiorum strain 1980 encodes five endo-PGs, four of which are expressed in culture or during infection (Li et al., 2004). The importance of polygalacturonases in plant diseases has been demonstrated for the pathogenic fungi Botrytis cinerea (ten Have et al., 1998), Alternaria citri (Isshiki et al., 2001), Claviceps purpurea (Oeser et al., 2002), and S. sclerotiorum (Kasza et al., 2004; Li et al., 2004).

Many plants possess a cell wall glycoprotein, polygalacturonase-inhibiting protein (PGIP), that is able to inhibit fungal PGs. The interaction between fungal PGs and plant PGIPs favors the accumulation of oligogalacturonides, which elicit a wide range of defense mechanisms (De Lorenzo et al., 2001; Ridley et al., 2001; De Lorenzo and Ferrari, 2002). A direct role for PGIPs in plant defense has been demonstrated recently where transgenic tomato and tobacco plants over-expressing PGIP showed a reduction in symptoms when infected by $B$. cinerea (Powell et al., 2000; Ferrari et al., 2003; Manfredini et al., 2005).

Recently, the development of expressed sequence tag resources, together with the 
availability of high-quality genomic libraries and the progress in sequence analysis tools, have allowed complete or extensive characterization of the PGIP gene families in Arabidopsis thaliana (L.) Heynh. (Ferrari et al., 2003) and Brassica napus L. (Li et al., 2003; Hegedus et al., 2008). In P. vulgaris, four genes code for proteins that show sequence variation from 3 to $24 \%$. These genes are grouped into two couples, Pvpgip1-Pvpgip2 and Pvpgip3-Pvpgip4, probably originating from independent events of gene duplication (D'Ovidio et al., 2004).

In order to compare the temporal expression of sspg and Pvpgip genes, we performed semi-quantitative reverse transcription polymerase chain reaction (PCR) and real-time PCR experiments on total RNA extracted from dry bean stems at different times following inoculation with S. sclerotiorum. Simultaneous analysis of sspg and Pvpgip expression during plant infection could better elucidate and substantiate the role of these different components in plant-pathogen interaction.

\section{MATERIAL AND METHODS}

\section{Infection and bean tissue sampling}

S. sclerotiorum isolate SPS was collected from a naturally infected bean plant and grown on Petri dishes containing potato-dextrose agar culture medium for 5 days at $20^{\circ} \mathrm{C}$. After this growth period, $1-\mathrm{cm}$ long toothpick ends poked into culture medium were wrapped by the pathogen mycelia, which were used to inoculate dry bean plants afterwards. Plants of the dry bean cultivar Pérola were grown in a greenhouse at Embrapa Arroz e Feijão (Santo Antônio de Goiás, GO, Brazil), in 2-kg plastic pots with red yellow latosol soil that was treated with $5 \mathrm{~g}$ 4-30-16 NPK fertilizer. The inoculation was performed 10 days after emergence by introducing the toothpick ends wrapped with the pathogen mycelia into the base of the stems $1.0 \mathrm{~cm}$ above the soil surface. Plants that were mechanically wounded by introducing a toothpick without fungi into the base of their stems were used as an experimental control. All plants were kept at $20^{\circ} \mathrm{C}$ and $90 \%$ relative humidity for $48 \mathrm{~h}$ to provide adequate conditions for infection. Tissue samples were collected from both the necrotic part and the chlorotic area of each lesion within $2 \mathrm{~cm}$ of the lesion edges at $24,48,72$, and $96 \mathrm{~h}$ post-inoculation (hpi) and immediately frozen in liquid nitrogen prior to RNA and protein extraction.

\section{Semi-quantitative reverse transcription PCR}

RNA was extracted from plant tissues and fungal material using the standard Trizol protocol (Gibco-BRL). To remove any genomic DNA contamination, RNA was treated with RNAse-free DNAse I (Promega) followed by enzyme inactivation $\left(2.5 \mathrm{mM}\right.$ EDTA, $65^{\circ} \mathrm{C} / 10$ min) and ethanol precipitation.

The transcriptional analyses of fungal pg (sspg) and plant pgip (Pvpgip) genes were carried out employing semi-quantitative reverse transcription PCR and the following oligonucleotide primers specific for $p g$ sequences: sspgl (AF501307) [pg1R: 5'-TCT TGC AGC AGT CGA GAA GA-3'; pg1F: 5'-GTG TTG TGT CCG AGG GAG TT-3']; sspg3 (AY312510) [pg3R: 5'-ACC CAC CAC TTT GGC TAC TG-3'; pg3F: 5'-TGA GAC GGT AAG ACC CTT GG-3']; sspg5 (AY496277) [pg5R: 5'-TGT CCA AGT TTT CAG TAT T-3'; pg5F: 5'-CTA CCA GCA TTT CCA TTA T-3'], and sspg6 (AF501308) [pg6R: 5'-CAA GCT TAT TGG AAT 
GGG TAT-3'; pg6F: 5'-CTG GAG TTG ACG ATT TGA CTA-3']. The sizes of all amplified fragments were $495,448,452$, and $462 \mathrm{bp}$, respectively. The $28 \mathrm{~S}$ rDNA gene-specific primers [rDNA-F (5'-GGT GGA GTG ATT TGT CTG-3') and rDNA-R (5'-CTT ACT AGG GAT TCC TCG-3')] were designed according to 28S rDNA gene of S. sclerotiorum. These pairs of primers were used to amplify a 600-bp cDNA product that acted as a control in the reverse transcription PCR experiments.

Transcripts of PGIP were amplified using specific primers for Pvpgip1, Pvpgip2 (both Pvpgip2.1 and Pvpgip2.2), Pvpgip3, and Pvpgip4 as described by D'Ovidio et al. (2004).

First strand cDNA was synthesized using $2 \mu \mathrm{g}$ DNAse-treated total RNA using superscript II Reverse Transcriptase (Gibco-BRL), following the supplier recommendations. We amplified $5 \mu \mathrm{L}$ of first strand cDNA in a final reaction volume of $25 \mu \mathrm{L}$ containing $1 \mathrm{X}$ Taq DNA polymerase buffer, $1.5 \mathrm{mM} \mathrm{MgCl}, 0.2 \mathrm{mM}$ dNTPs, $0.2 \mu \mathrm{M}$ specific primers, and $5 \mathrm{U}$ Taq DNA polymerase (Gibco-BRL). PCR was initially performed at $94^{\circ} \mathrm{C}$ for $4 \mathrm{~min}$, and then 27 cycles as follows: $94^{\circ} \mathrm{C}$ for $1 \mathrm{~min}, 55^{\circ} \mathrm{C}$ for $1 \mathrm{~min}$, and $72^{\circ} \mathrm{C}$ for $1 \mathrm{~min}$. PCR products were resolved by electrophoresis on a $1.2 \% \mathrm{w} / \mathrm{v}$ agarose gel. Two replicates of reverse transcription PCR experiments were performed for all genes analyzed. To quantify the gene expression levels, we employed densitometry analysis (Scion Image software) available online (http://www. scioncorp.com). Amplified product intensity was expressed as relative absorbance units. The ratio between the relative absorbance units determined for the amplified gene of interest and internal control was calculated to normalize for initial variations in sample concentration and as a control for reaction efficiency.

\section{Real-time PCR}

The sequences of primers used were: Pvpgip1 (AJ864506.1) [pgip1 F - CGC CTC ACC GGG AAG AT; pgip1 R - TGT TCC GAG ACA AGT CAA CGA A]; Pvpgip2 (AJ864507.1) [pgip2 F - TTC GAC GGC AAC CGA ATC; pgip2 R - TGG TCA TCG ACG TAA ACA GCT T]; Pvpgip3 (AJ864508.1) [pgip3 F - TCC TTC CCG AAG CAT TTC AC; pgip3 R - GCG TCG CCG GTA TAT TGC]; Pvpgip4 (AJ864509.1) [pgip4 F - TCC TTC CCG AAG CAT TTC AC; pgip4 R - GCC AGC GTC GTC GGA ATA T], and actin gene (act) of $P$. vulgaris (Q11197) [act-F - 5' CCC CAG CGT TCT ACG TCT 3', act-R - 5' CAT GTC AAC ACG AGC AAT G 3']. The sizes of all amplified fragments were 70, 76, 84, 106, and $92 \mathrm{bp}$ for Pvpgip1-4 and actin genes, respectively.

Equal amounts of RNA $(0.5 \mu \mathrm{g})$ were reverse-transcribed using oligo(dT)12-18 primer and submitted to real-time PCR. Amplification assays were carried out with a 7900HT Sequence Detection System ABI PRISM instrument (Applied Biosystems, USA) in 12- $\mu$ L reaction mixtures containing $0.4 \mu \mathrm{M}$ of each primer described above, $6 \mu \mathrm{L}$ SYBR Green PCR Master mix (2X), and $0.2 \mu \mathrm{L}$ template cDNA. After an initial denaturation step at $95^{\circ} \mathrm{C}$ for $10 \mathrm{~min}$, amplifications were carried out for 40 cycles at $95^{\circ} \mathrm{C}$ for $15 \mathrm{~s}$ and $60^{\circ} \mathrm{C}$ for $1 \mathrm{~min}$. To check the specificity of the PCR product, melting curves were analyzed for each data point. Relative gene expression was obtained with the formula: fold induction $=2^{[\Delta \Delta \mathrm{Ct}]}$, where $\Delta \Delta \mathrm{Ct}$ $=[\mathrm{Ct}$ GI (unknown sample) - Ct ACT (unknown sample)] - [Ct GI (reference sample) - Ct ACT (reference sample)]. GI is the gene of interest and ACT is the P. vulgaris actin gene used as internal control. The reference sample was chosen to represent $1 \mathrm{X}$ expression of the gene of interest. 


\section{Enzyme assay}

Polygalacturonase activity was quantified by recording the increase in absorbance at $575 \mathrm{~nm}$ caused by the release of reducing sugars from citrus pectin. The reaction mixture contained $25 \mu \mathrm{L}$ macerated tissue extract and $225 \mu \mathrm{L} 2 \mathrm{mg} / \mathrm{mL}$ citrus pectin dissolved in 0.1 $\mathrm{M}$ sodium acetate buffer, $\mathrm{pH}$ 5. After $30 \mathrm{~min}$ incubation at $45^{\circ} \mathrm{C}$, the reaction was stopped by the addition of $750 \mu \mathrm{L}$ dinitrosalicylic acid reagent, boiled for $5 \mathrm{~min}$, and cooled on ice (Miller, 1959). Enzyme and substrate controls were included in all assays. Enzyme activities are expressed as micrograms of reducing sugar released during 30-min incubation. Protein contents were determined using the Quant-iT Protein Assay kit (Invitrogen).

\section{RESULTS AND DISCUSSION}

Aiming at comparing the temporal expression of sspg and Pvpgip genes, semi-quantitative real-time PCR experiments were performed on total RNA extracted from bean stem lesions at different times after inoculation with $S$. sclerotiorum. These experiments were carried out employing specific primers directed to the internal control (rDNA 28S) and to the experimental sspg (sspg1, sspg3, sspg5, sspg6) and Pvpgip (Pvpgip1, Pvpgip2, Pvpgip3, Pvpgip4) genes. Afterward, we performed reverse transcription PCR product quantification using the appropriate analyses, which revealed that both sspg and Pvpgip genes showed high expression levels as a consequence of $S$. sclerotiorum infection.

\section{Expression of $S$. sclerotiorum $P G$ genes during pathogenesis}

Dry bean plants were effectively infected by S. sclerotiorum (Figure 1). During the first $24 \mathrm{hpi}$, a mycelial mass developed and invaded the tissues, but no macroscopic symptoms were detectable. At $48 \mathrm{hpi}$, a necrotic zone was observed around the inoculation site and at 72 hpi, abundant aerial mycelia emerged from plant decayed tissues, which showed maceration on the surface. From 96 hpi on, the mycelium became progressively less abundant while the plant tissues were totally macerated.

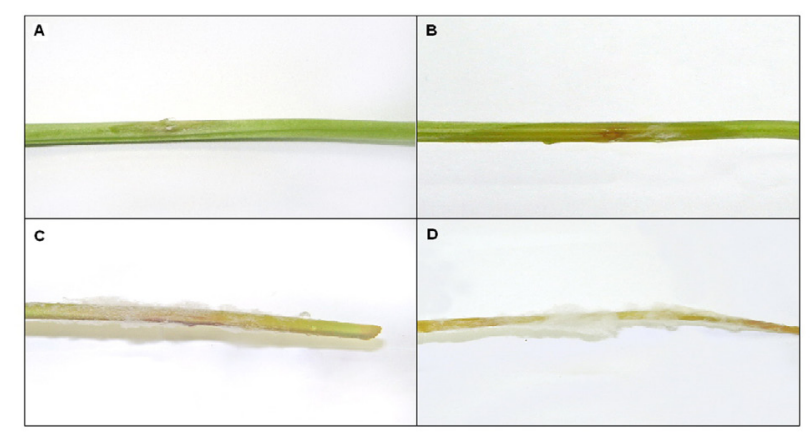

Figure 1. Sclerotinia sclerotiorum-infected bean stem at different times after inoculation. Inoculation performed 10 days after emergence, by introducing mycelium-colonized toothpick ends into the base of the stems $1.0 \mathrm{~cm}$ above the soil surface, which were removed to take the photograph in order to show the lesions at the following times: A. 24 hpi. B. 48 hpi. C. 72 hpi. D. 96 hpi. Tissue samples collected within $2 \mathrm{~cm}$ of the lesion margin. 
The expression of sspg genes was assessed in infected tissues to determine whether any of them could be associated with the infection process. Transcripts of the sspg1, sspg3, sspg5, and sspg6 genes were detected by semi-quantitative reverse transcription PCR at 24 hpi (Figure 2A,B). At this point, a mycelium developed and invaded the tissues, but no macroscopic symptoms were detectable.
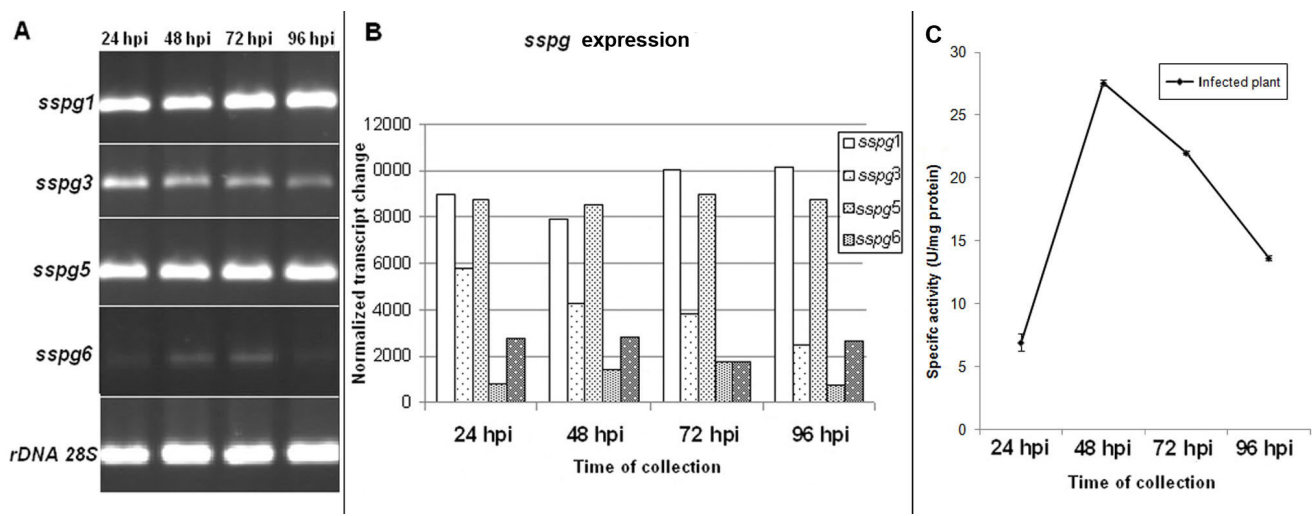

Figure 2. Expression pattern of polygalacturonase genes (sspg1, sspg3, sspg5, sspg6) of Sclerotinia sclerotiorum during pathogenesis of bean stems. A. Ethidium bromide-stained reverse transcription polymerase chain reaction (PCR) products: Tissue samples were collected from the necrotic part of each lesion 24, 48, 72, and 96 hpi. Total RNA was extracted and used in reverse transcription PCR experiments as described in the Material and Methods section. A fragment of rDNA was used to evaluate the presence of this fungus in the affected tissues. B. The quantitative analysis of sspg genes expression was performed by densitometry employing the Scion Image software (http://www.scioncorp.com). The sspg transcript levels were calculated in relation to the internal control. C. Endopolygalacturonase activity during pathogenesis of bean stems (see Material and Methods section).

The most significantly induced gene during the early phases of infection was sspgl, and the level of its transcript increased strongly at $96 \mathrm{hpi}$, when the stems were completely invaded by mycelia. Recent evidence suggests that sspg1 plays a role both in the initiation of the infection and in the subsequent lesion expansion during interaction of $S$. sclerotiorum with B. napus (Cessna et al., 2000; Li et al., 2004). In B. cinerea, the systematic appearance of individual PGs attests to the role that each plays in the infection process: Bcpg1 and Bcpg2 are expressed in the earliest stages of infection (ten Have et al., 2001), and mutants unable to produce BCPG1 exhibit reduced rates of lesion expansion (ten Have et al., 1998).

In our study, the sspg 3 gene was expressed during the initial phase of colonization of healthy plant tissues and peaked at $24 \mathrm{hpi}$, when the fungal biomass was very low. Its expression decreased at later stages of host colonization. This pattern of expression suggests that sspg3 may be more implicated in the early stages of host colonization than during the late stages of maceration of host tissues; sspg 5 was expressed at a high level 24 hpi and the transcripts accumulated between 72 and $96 \mathrm{hpi}$, the phase of invasive growth of the pathogen and progression of the necrotic zone; sspg 6 was regulated during the final phase of maceration and its transcript reached a maximum at $72 \mathrm{hpi}$, and then slightly decreased when the host tissues were macerated (96 hpi). A fragment of fungal 28S rRNA was amplified as a control for the amount of fungal RNA present in each sample. 
The expression timeframe of sspg genes was similar to those reported for $p g s$ of other S. sclerotiorum isolates (Cotton et al., 2002; Kasza et al., 2004; Li et al., 2004), although the respective patterns were different. For example, the expression of $p g 1$ precedes that of $p g 3$, pg5, and pg6 during infection of carrot roots with S. sclerotiorum (Kasza et al., 2004). In that pathosystem, pgl-3 genes were expressed during the phase of colonization of healthy plant tissues, whereas pg5 was transcribed during the final phase of maceration, and $p g 6$ and $p g 7$ exhibited a more constant expression pattern (Kasza et al., 2004). Studying B. napus leaves infected with S. sclerotiorum, Li et al. (2004) reported that sspgl gene was highly expressed during infection; sspg 3 was also expressed during the early phase of infection, although lower less than sspg1, whereas sspg5 and sspg6 were only weakly expressed. Curiously, our study indicates that sspg5 gene was highly expressed during the infection process.

Examination of the expression patterns of individual sspg genes has revealed that the interplay of PGs among themselves and with the host during the various stages of infection is finely coordinated. Early in pathogenesis, $S$. sclerotiorum secretes oxalic acid in infected tissues, which gradually lowers the neutral $\mathrm{pH}$ of the plant apoplasm. In the course of infection, acidification of the ambient medium and decay of the plant tissue polymers may create an environment conducive for early or constitutive PGs to attack the host cell wall, in turn releasing metabolites that serve to induce expression of other sspg genes (Fraissinet-Tachet and Févre, 1996; ten Have et al., 2001).

We also investigated whether the presence of multiple genes could respond to PG activity modulation. During the pathogenesis process in infected tissue, PG activity increased and peaked at approximately $48 \mathrm{~h}$, and then gradually decreased at the times evaluated (Figure 2C).

In addition to previous reports (Kasza et al., 2004; Li et al., 2004), our data indicate that sspg genes are differentially regulated under parasitic conditions, the expression of each of them being governed by a unique set of environmental and developmental factors. However, the specific role individual PG plays in the infection process remains to be elucidated.

\section{Members of the Pvpgip family are differentially regulated}

In order to verify whether the four Pvpgip genes display different regulation patterns following wounding and pathogen inoculation, we performed a semi-quantitative reverse transcription PCR analysis using specific primers for each gene. Transcript level analyses were performed on total RNA extracted from 1- to 4-day-old bean seedlings mechanically wounded or infected with $S$. sclerotiorum.

Even with a high number of amplification cycles and at an RNA template concentration higher than that used for the analysis of Pvpgip genes of infected samples, amplification of Pvpgip1-3 never occurred in RNA samples extracted from mechanically wounded plant tissues. Remarkably, only Pvpgip4 transcripts appeared to be induced by mechanical wounding (Figure 3A).

Densitometric analyses revealed that Pvpgip transcripts were differentially induced in dry bean stem tissue in response to S. sclerotiorum infection (Figure 3B). During the early phases of infection, Pvpgip1 transcripts were not detected, whereas their presence was revealed at 72-96 hpi, when the stems were completely invaded by mycelia. Pvpgip 2 levels were high in the initial phase of colonization and peaked at $48 \mathrm{hpi}$. The levels of transcript declined between 72 and 96 hpi as the plant tissue began to undergo necrosis. 


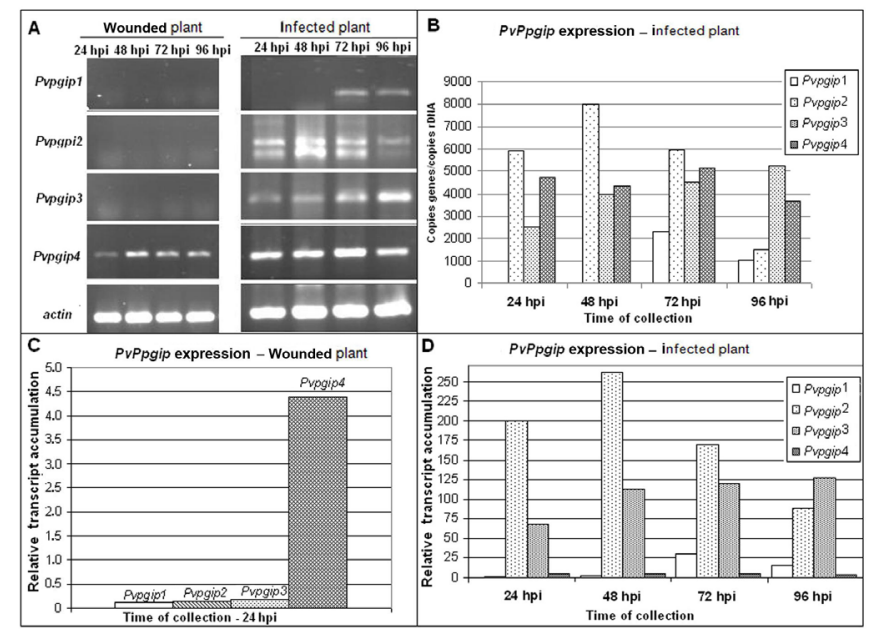

Figure 3. Differential expression of dry bean Pvpgip genes in response to infection with Sclerotinia sclerotiorum. A. Total RNA was extracted from bean stem at different times (24, 48, 72, and $96 \mathrm{~h}$ ) after wounding (wounded plant) or infection with $S$. sclerotiorum (infected plant). Reverse transcription polymerase chain reaction (PCR) experiments were carried out as described in the Material and Methods section. The sizes of the amplified DNA fragments are as follows: Pvpgip1 $=493$ bp; Pvpgip $2=443$ bp; Pvpgip $3=451$ bp; Pvpgip $4=445$ bp. $r D N A$ 28S gene was used to control the amount of mRNA present in each sample. B. Semi-quantitative analyses of Pvpgip expression in infected tissue were performed exactly as described in Figure 2. C. and D. Transcript accumulation of Pvpgip genes in wounded or infected plants. Real-time PCR analyses were performed and transcript levels were calculated from triplicate data using the standard curve method: C. P. vulgaris actin gene as internal control and health plant (at time zero) as reference sample; D. $P$. vulgaris actin gene as internal control and wounded plant (at respective time) as reference sample. The results represent the mean fold increase of mRNA level over wounded stem, plotted against the $1 \mathrm{X}$ expression level. Results are reported as means \pm standard deviation of three experiments.

Pvpgip3 expression increased strongly at $96 \mathrm{hpi}$. A reverse transcription PCR product derived from transcripts of Pvpgip 4 was present from 24 hpi until the end of the experiment, but its expression was detected at higher levels in the necrotic lesion area than in the mechanically wounded plant.

These expression data clearly characterize a sequential pattern of gene transcription and suggest that Pvpgip 2 may be more involved in the early stages of host defense and Pvpgip1 and Pvpgip3, during the late stages. This profile expression was confirmed by real-time PCR analyses.

Pvpgip genes are regulated during development and upon wounding and pathogen infection or treatments with eliciting agents such as salicylic acid and cold (De Lorenzo et al., 2001; Ferrari et al., 2003). Analyses performed by D'Ovidio et al. (2004) resulted in the identification of four Pvpgip in P. vulgaris. Furthermore, individual Pvpgip are differentially expressed in response to pathogen infection or treatments with elicitors: the expression of Pvpgip3 is induced by oligogalacturonides but not by fungal glucan, salicylic acid, or wounding; on the other hand, expression of Pvpgip4 is not altered by any of these treatments.

Expression of Pvpgip1 is induced by wounding only, whereas Pvpgip 2 is upregulated by oligogalacturonides, salicylic acid, and wounding. However, except for the amplification of Pvpgip1, which never occurred in RNA samples extracted at time 0 from either untreated tissues or suspension cultured cells, basal levels of transcripts of Pvpgip1, Pvpgip2, Pvpgip3, 
and Pvpgip4 were detected by reverse transcription PCR in all RNA samples extracted from bean hypocotyls at different times after wounding (D'Ovidio et al., 2004).

In contrast, we report here that transcripts of Pvpgip1, Pvpgip2, and Pvpgip3 were not detected by semi-quantitative reverse transcription PCR in bean stem upon wounding. In order to confirm their regulation, real-time PCR approach was used. Primers specific for Pvpgipl, Pvpgip2, Pvpgip3, and Pvpgip4 were synthesized (see Material and Methods section).

Real-time PCR analyses revealed very low basal levels of Pvpgip1, Pvpgip2, and Pvpgip3 genes in P. vulgaris stems $24 \mathrm{~h}$ after wounding (Figure 3C). The values represent a higher number of transcripts in relation to the healthy plants used as reference in these analyses. Such discrepancies between data attained on bean hypocotyls (D'Ovidio et al., 2004) and those obtained on stem, however, are not surprising because additional factors occurring in plant tissue may condition PG activity or PG-PGIP interaction. Although other factors such as cultivar, phase of plant development, and cultivation conditions may have influenced the expression of Pvpgip, further studies are necessary to prove this.

In infected bean stem, the expression of Pvpgip1, Pvpgip2, Pvpgip3, and Pvpgip4 genes was rapidly and transiently upregulated (Figure 3D). Compared to the expression in injured plants, induction of Pvpgip genes during stem infection by S. sclerotiorum peaked at: 48 hpi for Pvpgip2, showing a 262-fold increase in the amount of transcripts; 96 hpi for Pvpgip3, with a 112-fold increase; 72 hpi for Pvpgip1, with a 27.2-fold increase, and Pvpgip4 showing an average of 4.9-fold increase at the times evaluated. Transcript accumulation of these genes slowly decreased until 96 hpi. Similar expression profiles were previously observed by semi-quantitative reverse transcription PCR.

Remarkably, Pvpgip2 gene, which encodes the most efficient inhibitor of fungal PGs characterized so far (D'Ovidio et al., 2004; Manfredini et al., 2005), was the family member most upregulated by infection stimuli. Pvpgip2 has been previously found to have different types of inhibition, which suggests that the inhibitor adapts the recognition capabilities of its wide concave surface in many ways and against different epitopes of different PG ligands (Sicilia et al., 2005).

Plant defenses against fungal pathogens consist of both a localized response that is often associated with an oxidative burst and a more generalized systemic response mediated by signaling molecules. PGIPs have been shown to halt fungal invasion in plants. Following inoculation with $B$. cinerea, transgenic tomato and grapevine plants overexpressing a pgip gene from pear (Powell et al., 2000; Agüero et al., 2005), Arabidopsis plants overexpressing two endogenous pgip genes (Ferrari et al., 2003), and tobacco plants overexpressing bean Pvpgip2 (Manfredini et al., 2005) developed smaller lesions than those in wild-type plants, suggesting that PGIPs play a role in the innate immunity of plants and contribute to their basal resistance against fungi.

The PG-PGIP interaction limits the aggressive potential of PGs and favors the accumulation of elicitor-active oligogalacturonides in the apoplast (De Lorenzo and Ferrari, 2002). Oligogalacturonides are general elicitors of a wide number of plant defenses, including accumulation of phytoalexins, synthesis of lignin, expression of $\beta$-1,3-glucanase and proteinase inhibitors, and production of reactive oxygen species (Ridley et al., 2001; De Lorenzo and Ferrari, 2002). PGs are also capable of initiating programmed cell death in the host leading to tissue necrosis, a phenomenon that is circumvented by PGIPs (Zuppini et al., 2005). The capacity of PGs to elicit defense responses unrelated to their enzymatic activity has been recently proposed for $B$. cinerea-grapevine interaction (Poinssot et al., 2003). However, 
the enzymatic activity of PG from Colletrotrichum lindemuthianum has been shown to be essential for activating protective responses in tobacco (Boudart et al., 2003).

We showed different temporal expression of $p g$ and Pvpgip genes in the course of bean stem infection. Our results seem to be consistent with a maximization of fungal PG activity in the host tissue. By promoting the release of plant cell wall polysaccharide fragments and releasing oligogalacturonides, which are powerful signaling molecules, this enzyme may also activate plant defenses such as the increased expression of polygalacturonase inhibitor proteins. Future studies will aim at identifying cell surface proteins specifically induced during the first steps of pathogenesis by a proteomic approach. This should help unravel the complex developmental program underlying the infection process. In order to improve plant resistance through a PGIP-based strategy, knowledge of specific relationships between PGs and PGIPs is crucial.

\section{ACKNOWLEDGMENTS} nológico $(\mathrm{CNPq})$.

Research supported by Conselho Nacional de Desenvolvimento Científico e Tec-

\section{REFERENCES}

Agüero CB, Uratsu SL, Greve C, Powell ALT, et al. (2005). Evaluation of tolerance to Pierce's disease and Botrytis in transgenic plants of Vitis vinifera L. expressing the pear PGIP gene. Mol. Plant. Pathol. 6: 43-51.

Alghisi P and Favaron F (1995). Pectin-degrading enzymes and plant-parasite interactions. Eur. J. Plant. Pathol. 101: 365-375. Annis SL and Goodwin PH (1997). Recent advances in the molecular genetics of plant cell wall-degrading enzymes produced by plant pathogenic fungi. Eur. J. Plant Pathol. 103: 1-14.

Boland GJ and Hall R (1994). Index of plant hosts of Sclerotinia sclerotiorum. Can. J. Plant Pathol. 16: 93-108.

Boudart G, Charpentier M, Lafitte C, Martinez Y, et al. (2003). Elicitor activity of a fungal endopolygalacturonase in tobacco requires a functional catalytic site and cell wall localization. Plant Physiol. 131: 93-101.

Cessna SG, Sears VE, Dickman MB and Low PS (2000). Oxalic acid, a pathogenicity factor for Sclerotinia sclerotiorum, suppresses the oxidative burst of the host plant. Plant Cell 12: 2191-2200.

Cotton P, Rascle C and Fevre M (2002). Characterization of PG2, an early endoPG produced by Sclerotinia sclerotiorum, expressed in yeast. FEMS Microbiol. Lett. 213: 239-244.

D’Ovidio R, Raiola A, Capodicasa C, Devoto A, et al. (2004). Characterization of the complex locus of bean encoding polygalacturonase-inhibiting proteins reveals subfunctionalization for defense against fungi and insects. Plant Physiol. 135: 2424-2435.

De Lorenzo G and Ferrari S (2002). Polygalacturonase-inhibiting proteins in defense against phytopathogenic fungi. Curr. Opin. Plant Biol. 5: 295-299.

De Lorenzo G, D’Ovidio R and Cervone F (2001). The role of polygalacturonase-inhibiting proteins (PGIPs) in defense against pathogenic fungi. Annu. Rev. Phytopathol. 39: 313-335.

Ferrari S, Vairo D, Ausubel FM, Cervone F, et al. (2003). Tandemly duplicated Arabidopsis genes that encode polygalacturonase-inhibiting proteins are regulated coordinately by different signal transduction pathways in response to fungal infection. Plant Cell 15: 93-106.

Fraissinet-Tachet L and Févre M (1996). Regulation by galacturonic acid of pectinolytic enzyme production by Sclerotinia sclerotiorum. Curr. Microbiol. 33: 49-53.

Hegedus DD, Li R, Buchwaldt L, Parkin I, et al. (2008). Brassica napus possesses an expanded set of polygalacturonase inhibitor protein genes that are differentially regulated in response to Sclerotinia sclerotiorum infection, wounding and defense hormone treatment. Planta 228: 241-253.

Isshiki A, Akimitsu K, Yamamoto M and Yamamoto H (2001). Endopolygalacturonase is essential for citrus black rot caused by Alternaria citri but not brown spot caused by Alternaria alternata. Mol. Plant Microbe Interact. 14: 749-757.

Kasza Z, Vagvolgyi C, Fevre M and Cotton P (2004). Molecular characterization and in planta detection of Sclerotinia sclerotiorum endopolygalacturonase genes. Curr. Microbiol. 48: 208-213.

Li R, Rimmer R, Yu M, Sharpe AG, et al. (2003). Two Brassica napus polygalacturonase inhibitory protein genes are 
expressed at different levels in response to biotic and abiotic stresses. Planta 217: 299-308.

Li R, Rimmer R, Buchwaldt L, Sharpe AG, et al. (2004). Interaction of Sclerotinia sclerotiorum with Brassica napus: cloning and characterization of endo- and exo-polygalacturonases expressed during saprophytic and parasitic modes. Fungal Genet. Biol. 41: 754-765.

Manfredini C, Sicilia F, Ferrari S, Pontiggia D, et al. (2005). Polygalacturonase-inhibiting protein 2 of Phaseolus vulgaris inhibits BcPG1, a polygalacturonase of Botrytis cinerea important for pathogenicity, and protects transgenic plants from infection. Physiol. Mol. Plant Pathol. 67: 108-115.

Miller GL (1959). Use of dinitrosalicylic acid reagent for determination of reducing sugars. Anal. Chem. 31: 426-428.

Oeser B, Heidrich PM, Muller U, Tudzynski P, et al. (2002). Polygalacturonase is a pathogenicity factor in the Claviceps purpurea/rye interaction. Fungal Genet. Biol. 36: 176-186.

Poinssot B, Vandelle E, Bentejac M, Adrian M, et al. (2003). The endopolygalacturonase 1 from Botrytis cinerea activates grapevine defense reactions unrelated to its enzymatic activity. Mol. Plant Microbe Interact. 16: 553-564.

Powell AL, van Kan J, ten Have A, Visser J, et al. (2000). Transgenic expression of pear PGIP in tomato limits fungal colonization. Mol. Plant Microbe Interact. 13: 942-950.

Ridley BL, O’Neill MA and Mohnen D (2001). Pectins: structure, biosynthesis, and oligogalacturonide-related signaling. Phytochemistry 57: 929-967.

Sicilia F, Fernandez-Recio J, Caprari C, De Lorenzo G, et al. (2005). The polygalacturonase-inhibiting protein PGIP2 of Phaseolus vulgaris has evolved a mixed mode of inhibition of endopolygalacturonase PG1 of Botrytis cinerea. Plant Physiol. 139: 1380-1388.

ten Have A, Mulder W, Visser J and van Kan JA (1998). The endopolygalacturonase gene Bcpg1 is required for full virulence of Botrytis cinerea. Mol. Plant Microbe Interact. 11: 1009-1016.

ten Have A, Breuil WO, Wubben JP, Visser J, et al. (2001). Botrytis cinerea endopolygalacturonase genes are differentially expressed in various plant tissues. Fungal Genet. Biol. 33: 97-105.

Zuppini A, Navazio L, Sella L, Castiglioni C, et al. (2005). An endopolygalacturonase from Sclerotinia sclerotiorum induces calcium-mediated signaling and programmed cell death in soybean cells. Mol. Plant Microbe Interact. 18: 849-855. 